\title{
Influence of Cane Regulation on Yield of Wine Grapes under Northern Dry Zone of Karnataka, India
}

\author{
Ashwini, S. Ganur*, Kulapati Hipparagi, D.R. Patil, G.C. Sandhya and S.C. Suhansini \\ Department of Fruit Science, College of Horticulture, University of Horticultural Sciences, \\ Udyanagiri, Bagalkot-587104, Karnataka, India
}

*Corresponding author

\begin{tabular}{|l|}
\hline Key w or d s \\
Wine Grape, \\
Canopy, Growth \\
and Yield
\end{tabular}

A B S T R A C T
An investigation was conducted to know the "Impact of canopy management on growth and yield of wine grapes under northern dry zone of Karnataka" at division of fruit science at sector 70, UHS, Bagalkot during 2015-16. For the study varieties and cane regulation were considered as main and sub treatments respectively. Among varieties, Shiraz recorded to be early variety with early panicle initiation (17.33 days) and duration of maturity (114.25 days). Medika reported to be superior over other varieties with respect bunch breadth $(9.59 \mathrm{~cm})$, weight $(326.50 \mathrm{~g})$ and berry characters $(12.56 \times 12.26 \mathrm{~mm} \mathrm{LxB}$ and $2.02 \mathrm{~g}$ weight) which attributed for higher yield (13.97 kg/vine and $29.84 \mathrm{t} / \mathrm{ha})$. Cane regulation treatment significantly influenced on the yield and yield attributing parameters. Twenty five canes per vine was found to be superior over other treatments with respect to early panicle initiation (18.22 days), early maturation (116.00 days), number of panicles per cane (3.43), number of bunches per cane (2.08), bunch characters $(24.22 \times 9.33 \mathrm{~mm}$ LxB and $299.78 \mathrm{~g}$ weight) and berry characters (12.77 x $12.92 \mathrm{~mm}$ and $2.41 \mathrm{~g})$. Control treatment recorded significantly the maximum number of panicles per vine (86.44) and bunches per vine (66.56) which attributed to greater yield $(15.15 \mathrm{~kg} / \mathrm{vine}$ and $33.65 \mathrm{t} / \mathrm{ha})$. From the study, cane regulation is essential form of thinning in vineyard operation and considered as a technique which could lead to tremendous improvement wine grapes and helpful for quality wine production.

\section{Introduction}

Grape (Vitis vinifera L.) belongs to the family Vitaceae, originated in Caucasia or Asia Minor. The grape is one of the ancient fruit crops of India and which is cultivated in an area of 1.19 lakh hectare with the production of 25.85 lakh tons and productivity of 21.80 MT/ha (NHB, 2014). Historically, it is grown mostly for wine making in the world over. Wine grape cultivation is gaining strong impetus in tropical climatic conditions of the world. In contrast, prominent area and production accounts for table grapes in India, while wine grapes are grown over an area of 5.00 thousand hectares with annual production of 50.00 thousand tones for production of 25.00 million liters of wine (NHB, 2014).

In India, approximately 72-76 per cent of the production goes for table purpose, 22-24 per cent raisin, 3.50 per cent for wine and 0.50 per 
cent for juice due to limited domestic consumption of wine (annual per capita consumption of wine in the country is a mere 9 milliliters, approximately 1/8000th that of France).

In wine grapes, quality characters of grapes are more important than the yield. Quality is generally influenced by canopy management. Among the viticulture practices, crop load adjustment should be considered as one of the technical cultural practices suitable to modify grapevine physiology and plant production towards a defined goal (Mattii and Ferrini, 2005). Higher number of shoots per vine, i.e. increased shoot density impairs the productivity of shoots. Therefore, foundation pruning is done to develop shoots at this rate and their vigour may be curtailed by either pinching or thinning of shoots.

Taking into account, the fruit production habit wherein the plants produce clusters in the last growth branches (vine leaves) that originate in the development of the previous season (vine shoots), cane regulation is used to limit the number of canes, creating a balance between vigour and production, regulating the productive and vegetative potential and avoiding the aging of the vine. Therefore, cane regulation allows for the distribution of load units in the plants and yields in the good number of berry and size of the clusters with better quality.

In the present investigation, attempts were made to know the impact on growth and yield of vine by striking a balance between vigour and capacity through regulating the number of canes per vine in Shiraz Medika and Grenache Blanc

\section{Materials and Methods}

The study was conducted at the Division of Fruit Science, Sector 70, the Main
Horticultural Research and Extension Center, Bagalkot during 2015-16. It is situated under northern dry zone of Karnataka (Zone-3 and Region II) located at $16^{\circ} 10^{1}$ North latitude, $74^{\circ} 42^{1}$ East longitude with an altitude of 542 meters above the mean sea level. Bagalkot is influenced by both South-West and NorthEast monsoon. The average annual rainfall of $548 \mathrm{~mm}$, average temperature of $23.01^{\circ} \mathrm{C}$ and mean relative humidity ranged from $32-92$ per cent. The soil of the experiment site is red sandy loam with good physical properties and drainage. Nutrient status of the soil is 168.03 $\mathrm{kg} / \mathrm{ha} \mathrm{N}, 160.00 \mathrm{~kg} / \mathrm{ha} \mathrm{P}_{2} \mathrm{O}_{5}$ and $556.34 \mathrm{~kg} / \mathrm{ha}$ $\mathrm{K}_{2} \mathrm{O}$ with alkaline $\mathrm{pH}(8.05)$ and $0.15 \mathrm{dS} / \mathrm{m}$ EC.

The experimental design adopted for the present investigation was split plot design with three main treatments (Shiraz, Medika and Grenache Blanc) four sub treatments- cane regulation (C1- Control, C2-33 canes/vine, C3-33 canes/vine and C4-33 canes/vine) and replicated four times.

The number of days from pruning to visible bud sprouting, panicle initiation and days taken for harvesting in each treatment was counted and recorded in days. Number of panicles on each tagged cane and number of panicles per vine was counted and recorded in all the treatments.

The bunch parameters, length $(\mathrm{cm})$, weight $(\mathrm{g})$ and breadth $(\mathrm{cm})$ was measured, and mean were derived by averaging of five bunches during harvest.

Mean length $(\mathrm{mm})$ and diameter $(\mathrm{mm})$ of the berry obtained by measuring six berries on $120^{\text {th }}$ day with the help of digital vernier calipers and by weight $(\mathrm{g})$ of berry was derived by averaging the weight of six randomly selected berries. For the calculation of yield per vine $(\mathrm{kg})$, the mean bunch weight was multiplied by average number of bunches 
per vine. Yield t/ha was obtained by multiplying yield (kg/vine) with total number of vines per hectare.

Statistical analysis of the data was done by following the Fischer's method of analysis of variance as given by Panse and Sukhatme (1967). The level of significance used in ' $F$ ' and ' $\mathrm{t}$ ' test was $\mathrm{p}=0.05$ and critical difference (CD at 5\%) values were worked out whenever ' $F$ ' test was significant.

\section{Results and Discussion}

The data on influence of cane regulation on yield and yield attributing parameters are tabulated in Table 1. The perusal of data depicted as among the varieties, significance difference was found with respect to bud burst, duration of maturity, number of panicles per cane, number of panicles per vine, bunch characters, berry characters and yield.

Among varieties, the early bud burst, panicle initiation and duration of maturity was in Shiraz (10.75, 17.33 and 114.25, respectively) and late variety was Grenache Blanc (13.81, 21.83 and 128.08 , respectively) this might be due to Grenache Blanc genotypic character of late type, consumes more number of days to bud burst and panicle initiation and leading to the maximum duration of maturity. These findings are in agreement with Veena et al., (2015), white grape varieties takes more number of days to bud burst compared to black grape varieties.

Significantly, the highest number of panicles per cane and vine recorded in Grenache Blanc (4.16 and 105.50, respectively) and the lowest in Medika (2.39 and 59.42, respectively) because of the genotypic feature of Grenache Blanc with relation to maximum fruitful buds per cane might have resulted in the maximum number of panicles compared to other varieties.
This is in conformity with the findings of Veena et al., (2015) and Hachcholli et al., (2016) reported maximum number of bunches in Grenache Blanc.

Medika reported superior bunch (length 25.33 $\mathrm{cm}$, breadth $9.59 \mathrm{~cm}$, weight $326.50 \mathrm{~g}$ ) and berry characters (length- $12.56 \mathrm{~mm}$, breadth$12.26 \mathrm{~mm}$, weight- $2.02 \mathrm{~g}$ ) among varieties. Smaller bunch size (length- $20.33 \mathrm{~cm}$, breadth$8.89 \mathrm{~cm}$, weight-218.25 g) with small berries (length- $11.23 \mathrm{~mm}$, breadth- $11.93 \mathrm{~mm}$, weight- $1.39 \mathrm{~g}$ ) were found in Greneache Blanc because the genotypic character of this variety itself is to bear small size bunches. Whereas, Medika being a hybrid of Pusa Navarang and Flame Seedless, it might have inherited the characteristic of bold berry from the Flame Seedless.

The similar results were reported by Hachcholli et al., (2016) that among different wine varieties studied, Medika reported significantly superior over others in bunch and berry characters.

The perusal of data on yield per vine and yield per hectare revealed significant difference between the varieties (Table 1). Among the varieties, Grenache Blanc recorded the highest yield $(24.00 \mathrm{~kg})$ and the lowest was in Shiraz $(14.58 \mathrm{~kg})$. The reason might be genotypic character of the Shiraz to bear lesser number of berries per bunch, with average of two seeds per berry and lesser number of panicles. These results were in accordance with findings of Hachcholli et al., (2016) that among different genotypes of wine grapes, Grenache Blanc recorded the maximum number of panicles per vine (110.44) which contributed to the higher yield compared to Shiraz.

The data on the yield and yield attributing parameters revealed as significant difference among different levels of cane regulation (Table 1; Fig. 1-3). 
Fig.1 Influence of cane regulation on days taken for bud burst after fore-pruning

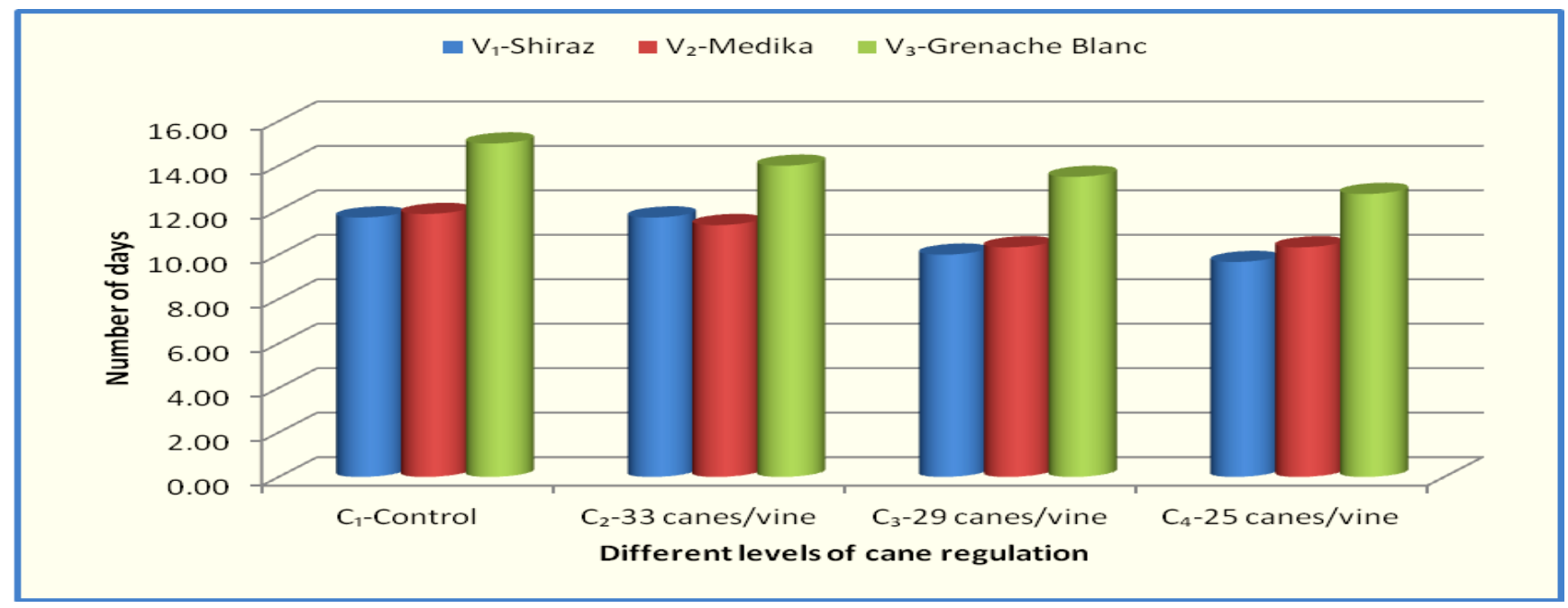

Fig.2 Influence of cane regulation on weight of the bunch

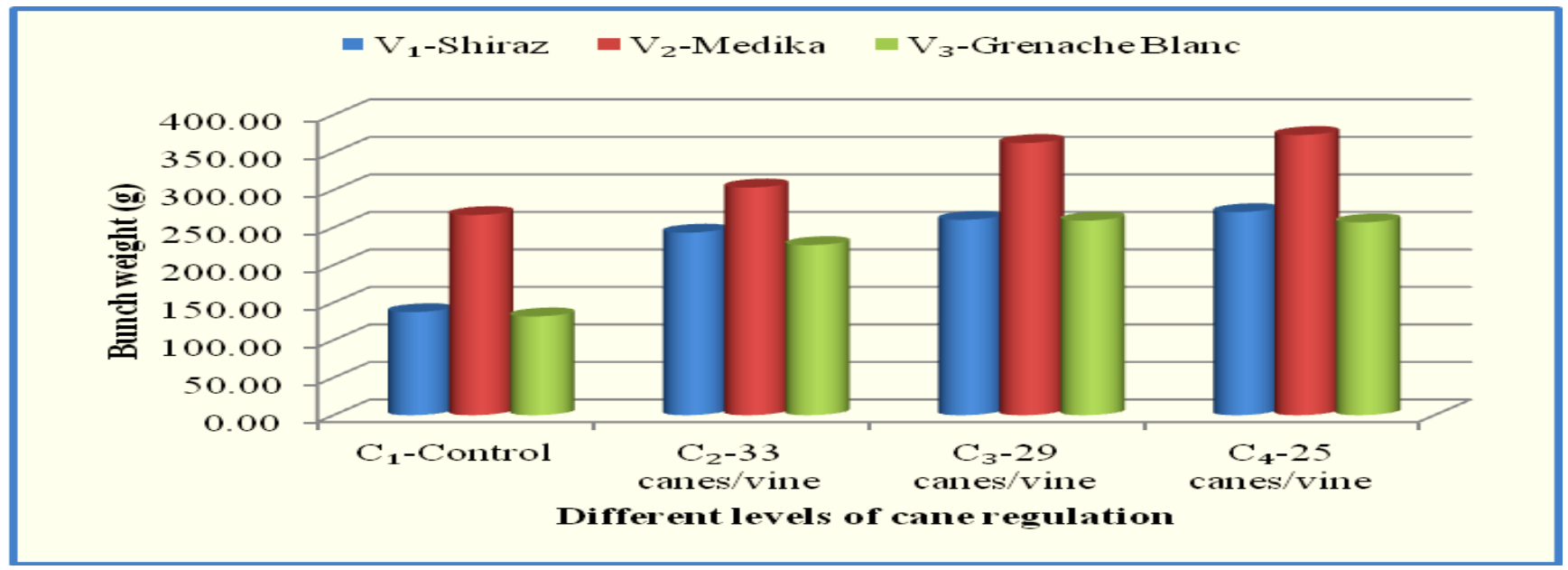

Fig.3 Influence of cane regulation on number of bunches per vine

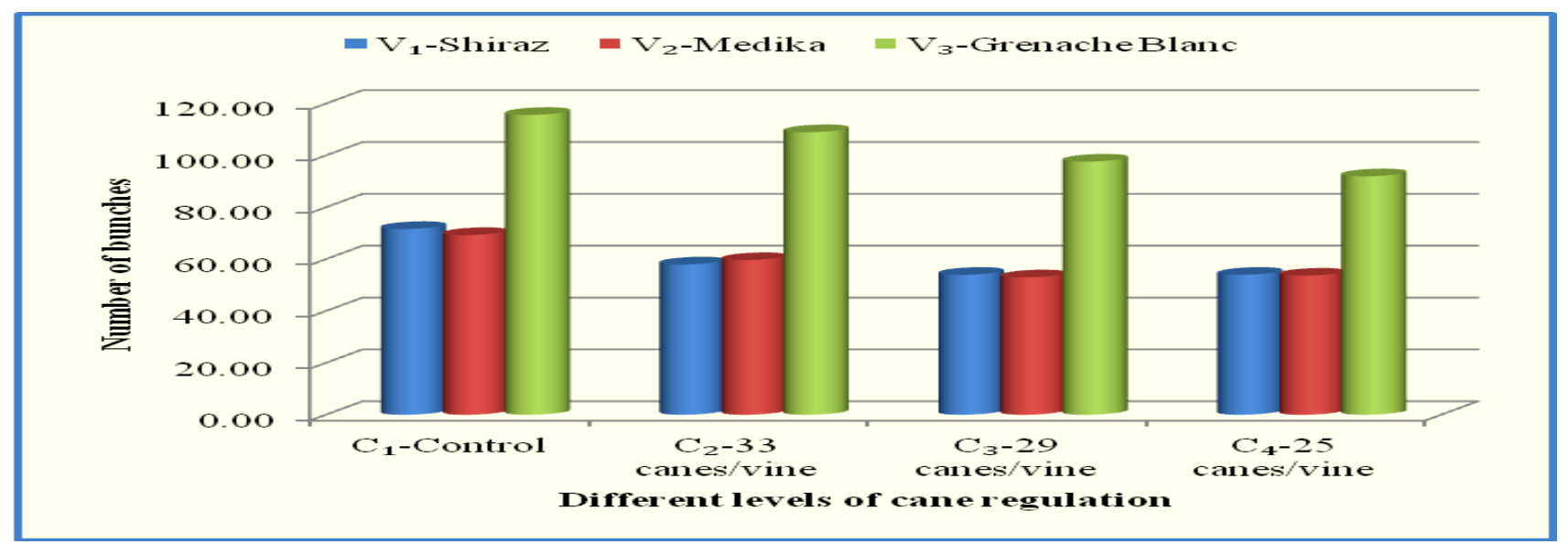


Table.1 Influence of cane regulation on yield and yield contributing parameters of wine grapes (Vitis vinifera L.)

\begin{tabular}{|c|c|c|c|c|c|c|c|c|c|c|c|c|c|c|}
\hline \multirow{2}{*}{\multicolumn{2}{|c|}{ Treatments }} & \multirow{2}{*}{$\begin{array}{c}\text { Bud } \\
\text { burst } \\
\text { (days) }\end{array}$} & \multirow{2}{*}{$\begin{array}{c}\text { Panicle } \\
\text { initiation } \\
\text { (days) }\end{array}$} & \multirow{2}{*}{$\begin{array}{c}\text { Duration } \\
\text { of } \\
\text { maturity } \\
\text { (days) }\end{array}$} & \multirow{2}{*}{$\begin{array}{c}\text { No. } \\
\text { Panicles } \\
\text { per } \\
\text { cane }\end{array}$} & \multirow{2}{*}{$\begin{array}{c}\text { No. } \\
\text { Panicles } \\
\text { per vine }\end{array}$} & \multicolumn{3}{|c|}{ Bunch characters } & \multicolumn{3}{|c|}{ Berry characters } & \multirow{2}{*}{$\begin{array}{c}\text { Yield } \\
\text { per vine } \\
\text { (kg/vine) }\end{array}$} & \multirow{2}{*}{$\begin{array}{l}\text { Yield } \\
\text { (t/ha) }\end{array}$} \\
\hline & & & & & & & $\begin{array}{c}\text { Length } \\
\text { (cm) }\end{array}$ & $\begin{array}{c}\text { Breadth } \\
\text { (cm) }\end{array}$ & $\begin{array}{c}\text { Weight } \\
\text { (g) }\end{array}$ & $\begin{array}{l}\text { Length } \\
\text { (cm) }\end{array}$ & $\begin{array}{c}\text { Breadth } \\
\quad(\mathrm{cm})\end{array}$ & $\begin{array}{c}\text { Weight } \\
\text { (g) }\end{array}$ & & \\
\hline \multicolumn{2}{|c|}{$\mathrm{V}_{1^{-}}$Shiraz } & 10.75 & 17.33 & 114.25 & 2.36 & 61.00 & 25.67 & 7.83 & 227.92 & 11.78 & 11.64 & 1.53 & 8.10 & 17.99 \\
\hline \multicolumn{2}{|c|}{$\mathrm{V}_{2-}$ Medika } & 10.96 & 18.17 & 115.67 & 2.39 & 59.42 & 25.33 & 9.59 & 326.50 & 12.56 & 12.26 & 2.02 & 12.32 & 31.02 \\
\hline \multicolumn{2}{|c|}{$\begin{array}{c}\mathrm{V}_{3} \text {-Grenache } \\
\text { Blanc } \\
\end{array}$} & 13.81 & 21.83 & 128.08 & 4.16 & 105.50 & 18.75 & 8.89 & 218.25 & 11.23 & 11.93 & 1.39 & 13.97 & 29.84 \\
\hline \multicolumn{2}{|c|}{ SEm \pm} & 0.22 & 0.69 & 2.63 & 0.09 & 0.65 & 0.55 & 0.20 & 6.37 & 0.12 & 0.30 & 0.16 & 0.23 & 0.52 \\
\hline \multicolumn{2}{|c|}{ C.D. at $5 \%$} & 0.60 & NS & 5.29 & 0.24 & 1.81 & 1.52 & 0.55 & 17.69 & 0.32 & NS & 0.45 & 0.63 & 1.45 \\
\hline \multicolumn{2}{|c|}{$\mathrm{C}_{1}$-Control } & 12.83 & 20.33 & 126.67 & 2.38 & 86.44 & 21.44 & 8.04 & 178.56 & 10.51 & 10.66 & 1.03 & 15.15 & 33.65 \\
\hline \multicolumn{2}{|c|}{$\begin{array}{c}\mathrm{C}_{2^{-}} \mathbf{3 3} \\
\text { canes/vine }\end{array}$} & 12.33 & 19 & 119.11 & 2.78 & 75.33 & 23.33 & 8.69 & 257.78 & 11.78 & 11.4 & 1.28 & 11.67 & 25.98 \\
\hline \multicolumn{2}{|c|}{$\mathrm{C}_{3}-29$ canes/vine } & 11.28 & 18.89 & 116 & 3.29 & 70.11 & 24 & 9.02 & 294.11 & 12.37 & 12.79 & 1.87 & 10.72 & 23.16 \\
\hline \multicolumn{2}{|c|}{$\mathrm{C}_{4}-25$ canes/vine } & 10.91 & 18.22 & 115.56 & 3.43 & 69.33 & 24.22 & 9.33 & 299.78 & 12.77 & 12.92 & 2.41 & 9.77 & 22.34 \\
\hline \multicolumn{2}{|c|}{ SEm \pm} & 0.35 & 1.09 & 4.03 & 0.17 & 0.93 & 0.97 & 0.44 & 7.08 & 0.30 & 0.26 & 0.19 & 0.35 & 0.65 \\
\hline \multicolumn{2}{|c|}{ C.D. at $5 \%$} & 0.73 & 2.29 & 8.46 & 0.36 & 1.96 & 2.04 & 0.92 & 14.88 & 0.63 & 0.55 & 0.39 & 0.74 & 1.36 \\
\hline SEm \pm & $\begin{array}{c}\text { V at } \\
\text { same or } \\
\text { different } \\
\text { C }\end{array}$ & 0.56 & 1.77 & 6.59 & 0.16 & 1.54 & 1.55 & 0.69 & 12.39 & 0.29 & 0.49 & 0.33 & 0.61 & 1.10 \\
\hline $\begin{array}{l}\text { C.D. } \\
\text { at } 5 \%\end{array}$ & $\begin{array}{c}\text { V at } \\
\text { same or } \\
\text { different } \\
\text { C }\end{array}$ & NS & NS & NS & NS & NS & NS & NS & & NS & NS & NS & 1.28 & 2.32 \\
\hline
\end{tabular}

V-Variety, C- Cane, NS- Not significant 
Twenty five canes per vine recorded the early bud burst (10.91 days), early panicle initiation (18.22 days), less duration of maturity (115.56 days), superior bunches (length 24.22 $\mathrm{cm}$, breadth $9.33 \mathrm{~cm}$ and weight $299.78 \mathrm{~g}$ ) and berry characters (length $12.77 \mathrm{~mm}$, breadth $12.92 \mathrm{~mm}$, weight $2.41 \mathrm{~g}$ ) vines without cane regulation treatment (control) recorded the late burst (12.83 days), late panicle initiation (20.33 days), maximum duration of maturity (126.67 days) and inferior bunch size (length $21.44 \mathrm{~cm}$, breadth $8.04 \mathrm{~cm}$ and $178.56 \mathrm{~g}$ weight) and berry characters (length $10.51 \mathrm{~mm}$, breadth 10.66 $\mathrm{mm}$ and weight $1.03 \mathrm{~g}$ ). Control treatment had more number of canes per vine which has resulted in late bearing and inferior bunches because of inverse relation between carbohydrate accumulation and cane regulation levels. High shoot density vine which also created the shady condition while cluster development hence delayed maturation and impacted on berry characters. This was strongly supported by the findings of Joon and Singh (1983), the number of days taken for sprouting, flowering and ripening was significantly affected by the intensity of pruning in Delight grapes. The bunches of vines pruned to two bud with 40 spurs treatments were at par and ripened earliest (152 days) and Bravdo et al., (1985) opined that, the higher crop load delayed the date of harvest in Cabernet Sauvignon

Whereas, cane regulation by shoot thinning might have increased the total photosynthetic capacity of leaf by better interception of light to the vines which resulted in higher accumulation of photosynthates in the developing clusters. Jogaiah et al., (2013) opined that due to diversion of photosynthates to the available bunches by reduced number of canes resulted in increased cane thickness, which attributed to bold berry size. Bunches developed on control vines showed lowest berry weight in Norton.
Trait yield showed significant difference among the different levels of cane regulation. Control treatment i.e. vines without cane regulation gave significantly the highest panicles per vine (86.44) and yield (15.15 $\mathrm{kg} /$ vine and $33.65 \mathrm{t} / \mathrm{ha}$ ) compared to 25 canes per vine, which recorded the lowest panicles per vine (18.22) and yield (9.77 kg/vine and $22.34 \mathrm{t} / \mathrm{ha}$ ). Reason for maximum yield in control might be positive correlation of number of canes per vine with the number of panicles, which contributed for the total yield of vine. But from perusal of yield data of cane regulated vines, even with reduction of 34,42 and 50 per cent of shoots the yield difference was only 07,20 , and 25 per cent respectively. Because cane regulated vines gave the higher bunches per cane and bold berries which compensated by heavy bunches. The similar trends were obtained by Myers et al., (2008) in Sangiovese grape vines, Somkuwar et al., (2010) in grape vines and Naor et al., (2002) reported that Sauvignon Blanc. Shoot thinning tended to reduce total yields, mainly due to a reduction in cluster numbers (Reynolds 2005).

Interaction of variety and cane regulation significantly, influenced on the yield trait. The maximum yield was noted in Grenache Blanc without cane regulation $(23.00 \mathrm{~kg} / \mathrm{vine}$ and $20.67 \mathrm{t} / \mathrm{ha}$ ) and minimum in Shiraz with 25 canes per vine $(6.33 \mathrm{~kg} /$ vine and 12.87 t/ha). This might be due to lesser response of Shiraz to cane regulation.

Among the varieties, Medika performed superior with respect yield and yield contributing parameters. Vines regulated with 25 to 29 canes produce the good quality grapes for preparing quality wine, even though, these treatments recorded lower yield than the control. From the study, it can be clearly stated as, cane regulation is essential form of thinning in vineyard operation and considered as a technique which could lead to 
tremendous improvement in quality parameters of wine grapes and helpful for quality wine production

\section{References}

Hachcholli, A., Hipparagi, K., Rani, S., Ravindranath and Balesh, G. 2016. Evaluation of wine grape varieties for growth and yield under northern dry zone of Karnataka. Indian J. Sci. Res. 5(2): 409-411.

Jogaiah, S., Striegler, K. R., Bergmeier and Harris, J. 2013. Influence of canopy management practices on canopy characteristics, yield, and fruit composition of 'Norton' grapes (Vitis aestivalis M.). International J. Fruit Sci.13: 444-458.

Joon, M. S. and Singh, I. S. 1983. Effect of intensity of pruning on ripening, yield and quality of Delight grapes. Haryana J. Hort. Sci. 12(1\&2): 44-47.

Matti, G. B. and Ferrini, F. 2005. The effect of crop load on Sangiovese grapevine. Acta Hort. 689: 239-242.

Myers, J. K., Wolpert, J. A. and Howell, G. S. 2008. Effect of shoot number on the leaf area and crop weight relationship of young Sangiovese grapevines. American J. Enol. Vitic. 59(4): 422-424.

Naor, A., Gal, Y. and Bravdo, B. 2002. Shoot and cluster thinning influence vegetative growth, fruit yield and wine quality of 'Sauvignon Blanc' Grapevines. J. American. Soc. Hort. Sci. 127(4): 628-634.

NHB-National Horticulture Board, Indian horticultural database 2014. www.nhb. gov.in.

Panse, V. G. and Sukhatme, P. V. 1967. Statistical methods for agricultural workers, ICAR publication, New Delhi. pp: 152-174.

Reynolds, A. G., Molek, T. and Savigny, C. 2005. Timing of shoot thinning in Vitis vinifera: impacts on yield and fruit composition variables. American $J$. Enol. Vitic. 56: 343-356.

Somkuwar, R. G., Ramteke, S. D. and Satisha, J. 2010. Effect of cluster clipping and berry thinning on yield and quality of Thompson Seedless grapes. Acta Hort. 758: 229-231.

\section{How to cite this article:}

Ashwini, S. Ganur, Kulapati Hipparagi, D.R. Patil, G.C. Sandhya and Suhansini, S.C. 2018. Influence of Cane Regulation on Yield of Wine Grapes under Northern Dry Zone of Karnataka, India. Int.J.Curr.Microbiol.App.Sci. 7(05): 194-200.

doi: https://doi.org/10.20546/ijcmas.2018.705.025 